and bladder in fourteen out of eighteen rats maintained on such low choline diets for five to eleven months.

Although it may seem disappointing that after so much study of cancer the fundamental cause or nature of it is unknown, the papers referred to above show advances. The carcinogenic process can often be influenced by diet, which means that the process can be resolved into separate parts, and this must help in the understanding of the process. Many of the speakers at the symposium compared carcinogenesis to mutations. Both cancer and mutations can be induced in living organisms by similar agents. The hypothesis that cancer is a somatic mutation relates carcinogenesis to other biological changes and the stability of the nuclear and cytoplasmic genes.

E. BOYLAND

\section{SURVEY OF RADIO NOISE}

$I^{\mathrm{T}}$

$T$ has long been appreciated that satisfactory radio communication depends upon the establishment at the receiving station of a minimum strength of signal above the prevailing noise. During the War, it became clear that the study of atmospheric noiselevel and the limitation which it imposes on signal reception has received far less attention in recent years than the study of radio wave propagation. In 1943, the Radio Research Board, in co-operation with British inter-Service organisations, considered that it was desirable to supplement our existing knowledge of the nature, origin and prevalence of atmospherics, with particular reference to their effect on radio reception in various parts of the world. It was recognized that this would involve the carrying out of a long-term programme of research in order to place our knowledge on a satisfactory basis in relation to other advances in radio reception technique. Before embarking upon such long-term research, the Board recommended that a survey of existing knowledge in this field should be made as soon as possible; and it is in consequence of this recommendation that Radio Research Special Report No. 15, entitled "Survey of Existing Information and Data on Radio Noise over the Frequency Range 1-30 Mc./s.", has recently been published by the Department of Scientific and Industrial Research (London: H.M. Stationery Office. 3s. net).

This report has been prepared in the Radio Division of the National Physical Laboratory by Dr. H. A. Thomas and Mr. R. E. Burgess. Some 180 published papers on the subject were examined, together with data and measurements made available by certain commercial and government organisations operating radio services in Great Britain. The report covers radio noise of all types, whether of atmospheric, cosmic or man-made origin; but the scope of the work has been limited to radio frequencies between 1 and $30 \mathrm{Mc} \cdot / \mathrm{s}$. (wave-lengths 10-300 metres), since most of the medium- and long-distance communication and broadcasting is conducted within this range, and the efficiency of such services is determined and even severely limited by the strength of the noise prevailing at the receiving station.

In most circumstances, atmospheric noise is the main factor limiting long-distance reception and communication; all thunderstorms, with their accompanying lightning flashes, within a range of several thousand miles are potential sources of dis- turbance. The most prominent centres of such storms are the large land areas, and particularly those in the tropies such as Africa and America during their local summer seasons, although these storm centres can drift out over the oceans to considerable distances. In each locality the thunderstorm activity varies with the season and during the day, and it is usually greatest under summer conditions and during the local afternoon. But the radio waves originating in a lightning flash can travel to great distances and may cause considerable disturbance at a receiving point where the above conditions do not apply.

The report deals also with the measurement of the strength of noise and its direction of arrival, and it is in these fields that active research is now in progress with the view both of obtaining a better understanding of the origin and nature of radio noise of all types, and also of developing techniques of limiting or mitigating the effects of these disturbances to radio communication. Such investigations are now being started in various parts of the world, and this report provides a good foundation as a comprehensive presentation of existing knowledge.

\section{FORTHCOMING EVENTS}

(Meetings marked with an asterisk * are open to the publie)

\section{Monday, January 19}

Royal PHysicar SOCIETY OF EDINBURG (at the Royal Scottish Geographical Society, Synod Hall, Castle Terrace, Edinburgh), at $5.15 \mathrm{p}$;.m.-Dr. James Davidson:" Biology and the Detection of Crime".

Chemitoal Socuetr, South Wates Section (joint meeting with the UNIVERSITY COLLFG OF SWANSEA STUDENTS' CHEMICAL SOCIETY, at University College, Swansea), at 6 p.m.-Dr. Philipp Gross : "Th hysical Chemistry of some Vacuum Metallurgical Processes".

INSTITUTE OF WELDING, NORTh LONDON BRANOH (at the Roya Society of Tropical Medicine and Hygiene, Manson House, 26 Portland Place, London, W.1), at 7.30 p.m.-Mr. S. M. Reisser: "The Welding of Bridges and Buildings".

$$
\text { Tuesday, January } 20
$$

ROYaL SOOIETY OF ARTS, DOMINIONS aND COLONIES SECTION (at John Adam Street, Adelphi, London, W.C.2), at 2.30 p.m.-Mr. A. T. Nohn Adam Street, Adelphi, London, W.;"

SOCIETY OF Chemidal INDUSTRY, AGRIOULTURE GROUP (in the Physical Chemistry Department, Royal College of Science, Imperia "Rstitute Road, London, S.W.7), at 2.30 p.m.-Dr. S. J. Rowland: "Recent Studies in the Composition of Milk"."

ROYAL ANTHROPOLOGTCAL INSTITUTE (at 21 Bedford Square, London, W.C.1), at 5 p.m.-Mr. John M. Mogey : "The Community in Ulster".

EUGENIOS Societr (at the Royal Society, Burlington House, Piccadilly, London, W.1), at 5.30 p.m.-Dr. H. Harris : "Sex Limitation in Human Genetics"."

INSTITUTION OF CIVIL ENGINEERS (at Great George Street, Iondon, S.W.1), at 5.30 p.m.- Symposium of Papers on "Winter Condition and the Civil Engineer".- (Mr. Stanley Mehew : "Roads"; Mr. W. K. Wallace: "Railways"; Mr. H. J. B. Manzont : "Municipal"; Mr. Ben Howorth: "Drainage and Inland Navigation"; Prof. D. Brunt, F.R.S.: "Meteorology".)

INSTITUTION OF EIfEOTRICAL ENGINEERS, RADIO SBCTION (at Savoy Place, Victoria Embankment, London, W.C.2), at 5.30 p.m.-Discussion on "To What Extent does Distortion Really Matter in the Transmission of Speech and Music ?" (to be opened by Mr. P. P. Eckersley).

Socifoty of Chemical Indostry, Chemionl Enginemaing Grodp (at the Geolorical SoAL INDUSTRY, CHEMICAL ENGINEERING GROUP (at the Geological Society of London, Burlington House, Piccadilly, London, W.1), at 5.30 ,p.

INSTITUTION OF THE RUBBER INDUSTRY (at Caxton Hall, Caxton Street, London, S.W.1). - "Industrial Design in the Rubber Industry"

\section{Wednesday, January 21}

Royal Mroroscoptcal Socthty (in the Hastings Hall, B.M.A. House, Tavistock Square, London, W.C.1), at 5 p.m.-Annual Meeting; Dr. R. J. Ludford: "Relation between Cellular Structure and Functional Activity" (Presidential Address).

INSTITUTION OF ELIFOTRIOAL ENGINEERS, TRANSMISSION SECTION INSTITUTION OF ELIFOTRIOAL ENGINEERS, TRANSMISSION SECTION
(at Savoy Place, Victoria Embankment, London, W.C.2), at 5.30 p.m (at Savoy Place, Victoria Embankment, London, W.C.2), at 5.30 p.m.
Mr. E. T. Norris : "The Lightning Strength of Power Transformers".

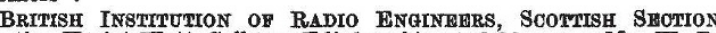
(at the Heriot-Watt College, Edinburgh), at 6.30 p.m. -Mr. W. D Oliphant: "Acceleration of Sub-Atomic Particles". 